\title{
Changes of some soil chemical and microbiological characteristics in a long-term fertilization experiment in Hungary
}

\author{
JÁNOS KÁTAI - MAGDOLNA TÁLLAI - IMRE VÁGÓ - \\ ANDREA BALLÁNÉ KOVÁCS
}

University of Debrecen, Faculty of Agricultural and Food Sciences and Environmental Management, Institute of Agricultural Chemistry and Soil Science, Debrecen, Hungary katai@agr.unideb.hu

\section{Summary}

Agricultural management practices - directly or indirectly - influence soil properties.

Fertilization rates and crop rotation can strongly affect soil $\mathrm{pH}$, soil nutrient supply and soil organic matter content due to the changes of microbial processes. The objective of this study was to compare the effects of different fertilization doses in monoculture and tri-culture of maize (monoculture: only maize grown since 1983, tri-culture: it is a three-year crop rotation system: pea - winter wheat maize) on selected soil characteristics. The long-term fertilization experiments were set up in 1983 in Eastern Hungary. These experiments are situated west of Debrecen in Hajdúság loess region, on calcareous chernozem (according to WRB: Chernozems).

The test plant was maize (Zea mays L.). One-one pilot blocks were selected from monoculture and tri-culture of the long-term experiments. The observed soil samples were taken in the $30^{\text {th }}$ year of the experiment, in 2013. The doses of NPKfertilizers increased parallel together, so the effects of N-, P- and K-fertilizers cannot be separated.

With the increasing fertilizer doses, the soil $\mathrm{pH}$ has decreased in both crop production systems and, in parallel, the hydrolytic acidity has significantly increased. A close negative correlation was proved between the $\mathrm{pH}_{\mathrm{H}_{2} \mathrm{O}}, \mathrm{pH}_{\mathrm{KCl}}$ and hydrolytic acidity. An increased nutrient content in soil was recorded in every NPK treatment and the available phosphorus and nitrate content increased in higher proportion than that of potassium.

Of the measured parameters of C-and N-cycles, fertilization has mostly had a positive effect on the microbial activity of soils. Besides the effects of fertilizer doses, correlation were looked for between soil microbiological properties. Evaluating the ratios among the measured parameters (organic carbon and microbial biomass carbon, $\mathrm{OC} / \mathrm{MBC}$ ratio; carbon-dioxide and microbial biomass carbon; $\mathrm{CO}_{2} / \mathrm{MBC}$ proportion), the fertilization rate seems to be favoured by the increase of amounts of organic compounds.

Keywords: $\mathrm{pH}$, soil acidity, nutrient content, organic matter, net nitrification, carbon-dioxide production, enzyme activities, microbial index 


\section{Introduction}

Nowadays, mankind is constantly growing on Earth, but the size of the arable land is decreasing. In the world, crop production is designed to maintain or increase the yield of plants grown by producing more and better quality food and feed raw materials. With this crop growing, it is very important to meet social needs around the world. Plant production has to adapt to the continuously changing environmental conditions along with selection of varieties and strive to apply technologies that do not pollute the environment and at the same time are economical.

In a long-term fertilization experiment in Debrecen-Látókép research station the response of maize to various agrotechnical elements and the influence of agrotechnical factors on soil have been examined for decades. Long-term experimental results show that the maize yield is basically determined by the soil properties. Maize is a nutrient-rich plant that utilizes the natural nutrient stock of the soil, but also requires a good plant nutrition (Pepó, 2001).

Agricultural management practices have - directly or indirectly impact on soil properties. Fertilization rates and crop rotation can also strongly affect the soil $\mathrm{pH}$, soil nutrient supply, and soil organic matter content due to change of microbial processes.

According to Sárvári (1995), the production of maize in monocultures is possible by the cultivation of well-adaptive hybrids, with a reduced number of plants, using irrigation. Cultivation of maize in monoculture is further restricted by the powerful appearance of maize beans (Diabrotica virgifera L.). The unfavourable effect of monoculture on the decrease of yield results is also needed to use larger amounts of fertilizer (Sárvári and Szabó, 1998).

The effect of the long-term fertilization experiment on soil chemical and microbiological properties has been investigated by many scientists (Powlson and Johnston, 1994; Kátai, 1999, 2014; Szili-Kovács et al., 2009; 2014; Janusauskaite et al., 2013; Zhao et al., 2013; Geisseler et al., 2014). The results showed that balanced nutrient supply has a beneficial effect on the cycle of the elements, the energy flow, the biodynamics and activity of soil organisms, as well as the growth and development of cultivated plants.

Pulleman et al. (2012) deal with soil biological indicators and monitoring systems, as well as date sets. With the application of these studies good opportunities can help the land management. The longterm experiments provide an excellent opportunity to determine the change in soil properties.

The objective of this study was to compare the effects of different fertilization doses in monoculture and tri-culture maize on some soil 
chemical and microbiological properties on the bases of our research work, in a Hungarian long-term plant nutrition experiment. Soil samples were taken in the $30^{\text {th }}$ years of the experiment, in 2013 spring. The results in mono- and tri-culture were evaluated separately.

\section{Materials and methods}

Experimental area

The Debrecen-Látókép long-term fertilization experiment can be found in the Eastern part of Hungary, $15 \mathrm{~km}$ west from Debrecen, on the "Hajdúság loess plateau". The soil type of the experiment is slightly leached calcareous chernozem (Chernozems in WRB) with loam texture. The fertilization experiment was set up in 1983. The effects of different fertilizer levels applied in maize monoculture and tri-culture were evaluated in non-irrigated conditions. Plants of crop rotation are pea, winter wheat and maize, the soil samples for the analysis were taken from the soil of maize. The treatments were applied as follows: control without any fertilization, small $\left(\mathrm{N}_{60} \mathrm{P}_{45} \mathrm{~K}_{45}\right)$, small-medium $\left(\mathrm{N}_{120} \mathrm{P}_{90} \mathrm{~K}_{90}\right)$, medium-large $\left(\mathrm{N}_{180} \mathrm{P}_{135} \mathrm{~K}_{135}\right)$ large $\left(\mathrm{N}_{240} \mathrm{P}_{180} \mathrm{~K}_{180}\right)$ doses as $\mathrm{N}, \mathrm{P}_{2} \mathrm{O}_{5}$ and $\mathrm{K}_{2} \mathrm{O}$.

\section{Soil parameters}

Moisture content (drying at $105^{\circ} \mathrm{C}$ for $24 \mathrm{~h}$ ), the $\mathrm{pH}$ in distilled water and $1 \mathrm{M}$ potassium chloride $(\mathrm{KCl})$ solution, ratio of soil/water $1 / 2.5 \mathrm{w} / \mathrm{w}$, and hydrolytic acidity ( $\left.\mathrm{y}_{1}\right)$ was measured by Buzás (1988).

The analysis of AL- $\mathrm{P}_{2} \mathrm{O}_{5}$ and $\mathrm{K}_{2} \mathrm{O}$ contents of the soil was based on Egner et al. (1960), the analysis of $\mathrm{NO}_{3}-\mathrm{N}$ content of soils was based on Felföldy (1987).

The organic carbon (OC) was determined by the methods of Székely et al. (1960), and the organic nitrogen (ON) by Tyurin (cit. Filep, 1988).

The microbial biomass carbon (MBC) and nitrogen (MBN) was measured by fumigation-extraction methods (Vance et al., 1987).

Net nitrification rate was measured after incubation (Felföldy, 1987). The soil respiration was determined after 10 days incubation with $\mathrm{NaOH}$ trapping (Öhlinger, 1996).

The phosphatase activity was measured by Öhlinger (1996) and the saccharase activity by the method of Frankenberger and Johanson (1983). The dehydrogenase activity was analysed by Mershi' methods (1996), and the urease activity was based on the quantitative determination of ammonia by the modified method of Kempers (cit. Filep, 1988).

Soil samples were taken in June of 2013 when the experiment was 30 years old. The measurements were done in three repetitions. 


\section{Statistical evaluation}

Along the evaluation the sampling average, standard deviation, variance analyses (One-way ANOVA - Duncan ${ }^{\mathrm{a}-t e s t)}$ were calculated $(n=3)$. Significant differences were calculated in the 5\%-level, applied generally in agricultural research. The statistical evaluation was made by using Excel 2013 and SPSS 13.0. Correlation (Pearson method-n=15) analyses were used to look for relationships between the microbiological soil properties.

\section{Results and discussion}

The changes of most important soil chemical and microbiological parameters are shown in Tables 1-3. In the two experimental blocks (mono- and tri-culture) there were very few differences in the moisture contents; they changed in a narrow interval (17.29-18.88\%).

Some important properties of soils examined

In parallel with increasing rates of fertilizer, the soil $\mathrm{pH}$ decreased significantly while the hydrolytic acidity has increased in all fertilized treatments at both crop rotations (Table 1).

Table 1. Effects of fertilization on the $\mathrm{pH}$ and on nutrient content in soils of experiment (Debrecen-Látókép Experiment, June 2013)

\begin{tabular}{|c|c|c|c|c|c|c|c|}
\hline \multirow[t]{2}{*}{ Treatments* } & \multirow{2}{*}{$\begin{array}{c}\begin{array}{c}\text { Moisture } \\
\text { content }\end{array} \\
(\%)\end{array}$} & \multirow{2}{*}{$\begin{array}{c}\mathrm{pH} \\
\mathrm{H}_{2} \mathrm{O}\end{array}$} & \multirow{2}{*}{$\begin{array}{l}\mathrm{pH} \\
1 \mathrm{M} \\
\mathrm{KCl}\end{array}$} & \multirow{2}{*}{$\begin{array}{l}\text { Hydrolytic } \\
\text { acidity (y1) }\end{array}$} & \multirow[t]{2}{*}{$\begin{array}{l}\mathrm{AL}- \\
\mathrm{P}_{2} \mathrm{O}_{5} \\
\end{array}$} & \multirow{2}{*}{$\frac{\mathrm{AL}-\mathrm{K}_{2} \mathrm{O}}{\left(\mathrm{mg} \mathrm{kg}^{-1}\right)}$} & \multirow[t]{2}{*}{$\mathrm{NO}_{3}-\mathrm{N}$} \\
\hline & & & & & & & \\
\hline \multicolumn{8}{|c|}{ Monoculture maize } \\
\hline Control & $17.73 b$ & $6.69 \mathrm{~d}$ & $5.55 c$ & $6.45 a$ & $19.33 a$ & $200.00 a$ & $21.24 \mathrm{a}$ \\
\hline $\mathrm{N}_{60} \mathrm{P}_{45} \mathrm{~K}_{45}$ & $17.78 b$ & $6.52 c$ & $5.43 c$ & $6.94 a$ & $30.33 b$ & $223.33 b$ & $24.27 \mathrm{ab}$ \\
\hline $\mathrm{N}_{120} \mathrm{P}_{90} \mathrm{~K}_{90}$ & $17.29 \mathrm{a}$ & $6.31 b$ & $5.12 b$ & $8.80 \mathrm{~b}$ & $68.33 c$ & $244.33 c$ & $25.97 \mathrm{ab}$ \\
\hline $\mathrm{N}_{180} \mathrm{P}_{135} \mathrm{~K}_{135}$ & $18.34 \mathrm{c}$ & $5.86 a$ & $4.89 a$ & $10.03 \mathrm{c}$ & $93.67 d$ & $256.00 \mathrm{~d}$ & $59.20 c$ \\
\hline $\mathrm{N}_{240} \mathrm{P}_{180} \mathrm{~K}_{180}$ & $18.12 \mathrm{~d}$ & $5.83 a$ & $4.86 \mathrm{a}$ & $11.08 \mathrm{~d}$ & $118.00 \mathrm{e}$ & $265.33 d$ & $30.02 b$ \\
\hline $\mathrm{LSD}_{5 \%}$ & 0.22 & 0.10 & 0.13 & 0.55 & 4.77 & 11.59 & 6.66 \\
\hline \multicolumn{8}{|c|}{ Tri-culture maize } \\
\hline Control & $18.88 b$ & $6.10 \mathrm{c}$ & $5.35 b$ & $10.90 \mathrm{a}$ & $18.67 \mathrm{a}$ & $192.67 \mathrm{a}$ & $23.02 a$ \\
\hline $\mathrm{N}_{60} \mathrm{P}_{45} \mathrm{~K}_{45}$ & $18.49 \mathrm{ab}$ & $6.02 c$ & $5.25 b$ & $11.31 \mathrm{ab}$ & $24.00 \mathrm{a}$ & $186.00 \mathrm{a}$ & $26.72 \mathrm{ab}$ \\
\hline $\mathrm{N}_{120} \mathrm{P}_{90} \mathrm{~K}_{90}$ & $18.37 \mathrm{ab}$ & $5.99 c$ & $5.01 \mathrm{ab}$ & $11.87 \mathrm{~b}$ & $60.33 c$ & $215.00 \mathrm{ab}$ & $30.70 b$ \\
\hline $\mathrm{N}_{180} \mathrm{P}_{135} \mathrm{~K}_{135}$ & $18.32 \mathrm{ab}$ & $5.68 \mathrm{~b}$ & $4.80 \mathrm{a}$ & $13.11 \mathrm{c}$ & $53.00 b$ & $237.33 b c$ & $111.58 \mathrm{c}$ \\
\hline $\mathrm{N}_{240} \mathrm{P}_{180} \mathrm{~K}_{180}$ & $18.00 \mathrm{a}$ & $5.50 \mathrm{a}$ & $4.73 a$ & $15.50 \mathrm{~d}$ & $82.67 \mathrm{~d}$ & $253.67 \mathrm{c}$ & $106.87 \mathrm{c}$ \\
\hline $\mathrm{LSD}_{5 \%}$ & 0.68 & 0.13 & 0.41 & 0.79 & 7.00 & 34.60 & 5.20 \\
\hline
\end{tabular}

Note: oneway ANOVA Duncan ${ }^{a}$ test $(n=3) .{ }^{*}$ The numbers in the lower case indexes indicates the yearly amount of applied fertilizers $\left(\mathrm{N}, \mathrm{P}_{2} \mathrm{O}_{5}\right.$ and $\left.\mathrm{K}_{2} \mathrm{O}\right), \mathrm{kg} \mathrm{ha}^{-1}$.

Both in mono- and tri-culture mainly the medium-large and the large doses of NPK fertilizer caused significant increases in acidity. Close 
negative correlation was found between the $\mathrm{pH}_{\mathrm{H}_{2} \mathrm{O}}, \mathrm{pH}_{\mathrm{KCl}}$ values and hydrolytic acidity in both crop rotations.

Regarding of the plant available nutrients of soil, an increased content can be recorded in every NPK treatments. The treatments of smallmedium, medium-large and large doses caused generally significant increase in the phosphorus, potassium and nitrate content of soil.

In monoculture, the phosphorus content of soils reached 4-5 times higher value by medium-large and the large fertilizer doses, compared to that of control plots. In these treatments a higher increase was found in monoculture than in tri-culture. The plant available potassium content of the soils increased by about $10-25 \%$ compared to the control, depending on the amount of fertilizer doses used. Similar changes were observed in both crop rotations. In the monoculture, the nitrate content of the soils increased by 1.5-3 times in comparison to the control, due to the medium-large and large fertilizer doses. In tri-culture, the nitrate content of soils increased by $4.5-5$ times in the same treatments.

In another 30-years long fertilization experiment (Nagyhörcsök, calcareous chernozem soil) Kádár (2003) found that in the upper soil layer the available phosphorus content increased nearly sevenfold and the potassium content doubled, compared to the phosphorus and potassium content of the control soil. In the long-term experiment (Görbeháza, in the $42-44^{\text {th }}$ years of the experiment), the nitrate content in the upper layer was 3-4 times higher than the control value (Kátai, 2015). In this experiment, phosphorus fertilization has increased the phosphorus content of the upper soil layer by $2.5-5$ times. Due to the fixation of potassium by clay minerals, the potassium content increased slightly, only by $10-30 \%$. In another long-term experiment in Karcag (on Meadow Chernozem soil type), the large amount of fertilization resulted a 3-fold increase in phosphorus content and 1.5 times the potassium content (Blaskó and Zsigrai, 2003). Kátai (2006) had previously reported that the fertilization has clearly increased the available nitrate, the ammonium-lactate soluble phosphorus and potassium content of soils in all experiment under the various cultures.

Evaluation of the organic matter content and mineralization processes in the soils of experiment

Our results demonstrate clearly that the organic carbon (OC) content of the experimental soils increased significantly in both crop rotations due to medium and larger fertilizer doses (Table 2). In the monoculture the organic nitrogen content remains essentially unchanged independently of the treatments, until in the tri-culture plots increased significantly due to fertilizer treatments. 
Table 2. The effect of fertilization on the organic matter content and mineralization processes in soil of experiment

(Debrecen-Látókép Experiment, June 2013)

\begin{tabular}{|c|c|c|c|c|c|c|}
\hline \multirow{2}{*}{ Treatments } & $\begin{array}{c}\text { Organic-C } \\
\text { (OC) }\end{array}$ & $\begin{array}{l}\text { Organic-N } \\
\text { (ON) }\end{array}$ & $\begin{array}{l}\qquad \mathrm{CO}_{2-} \\
\text { production }\end{array}$ & $\begin{array}{c}\text { Net } \\
\text { nitrification }\end{array}$ & $\mathrm{MBC}$ & MBN \\
\hline & \multicolumn{2}{|c|}{$\left(\mathrm{g} \mathrm{kg}^{-1}\right)$} & $\begin{array}{c}\text { (mg } 100 \text { g soil }^{-1} \\
\left.10 \text { days }^{-1}\right)\end{array}$ & $\left(\mathrm{NO}_{3}{ }^{-} \mu \mathrm{g} \mathrm{g}^{-1}\right)$ & \multicolumn{2}{|c|}{$\left(\mu \mathrm{g} g^{-1}\right)$} \\
\hline \multicolumn{7}{|c|}{ Monoculture maize } \\
\hline Control & $12.97 a$ & $1.70 \mathrm{a}$ & $13.46 a$ & $10.37 a$ & $46.94 a$ & $6.70 \mathrm{a}$ \\
\hline $\mathrm{N}_{60} \mathrm{P}_{45} \mathrm{~K}_{45}$ & $13.53 b$ & $1.64 \mathrm{a}$ & $13.93 \mathrm{ab}$ & 13.37ab & $96.29 b$ & $6.90 \mathrm{ab}$ \\
\hline $\mathrm{N}_{120} \mathrm{P}_{90} \mathrm{~K}_{90}$ & $13.37 b$ & $1.66 \mathrm{a}$ & $14.59 \mathrm{bc}$ & $14.74 \mathrm{~b}$ & $153.20 \mathrm{c}$ & $7.75 b c$ \\
\hline $\mathrm{N}_{180} \mathrm{P}_{135} \mathrm{~K}_{135}$ & $13.70 \mathrm{bc}$ & $1.68 \mathrm{a}$ & $17.25 \mathrm{~d}$ & $38.74 \mathrm{c}$ & $228.67 d$ & $8.57 \mathrm{~cd}$ \\
\hline $\mathrm{N}_{240} \mathrm{P}_{180} \mathrm{~K}_{180}$ & $14.00 \mathrm{c}$ & $1.67 \mathrm{a}$ & $15.00 \mathrm{c}$ & $46.34 d$ & $203.50 \mathrm{e}$ & $9.47 \mathrm{~d}$ \\
\hline $\mathrm{LSD}_{5 \%}$ & 0.35 & 0.07 & 0.66 & 3.95 & 13.34 & 0.97 \\
\hline \multicolumn{7}{|c|}{ Tri-culture maize } \\
\hline Control & $12.53 a$ & $1.83 a$ & $16.39 a$ & $9.43 a$ & $41.41 \mathrm{a}$ & $9.70 a$ \\
\hline $\mathrm{N}_{60} \mathrm{P}_{45} \mathrm{~K}_{45}$ & $12.60 \mathrm{a}$ & $1.90 \mathrm{~b}$ & $16.42 \mathrm{a}$ & $12.46 \mathrm{a}$ & $75.70 \mathrm{~b}$ & $11.24 b$ \\
\hline $\mathrm{N}_{120} \mathrm{P}_{90} \mathrm{~K}_{90}$ & $13.35 b$ & $1.91 \mathrm{bc}$ & $16.55 a$ & $21.69 \mathrm{~b}$ & $129.79 \mathrm{c}$ & $11.75 \mathrm{bc}$ \\
\hline $\mathrm{N}_{180} \mathrm{P}_{135} \mathrm{~K}_{135}$ & $13.79 \mathrm{c}$ & $1.98 \mathrm{~cd}$ & $17.66 \mathrm{~b}$ & $34.03 \mathrm{c}$ & $337.46 \mathrm{~d}$ & $12.56 \mathrm{~cd}$ \\
\hline $\mathrm{N}_{240} \mathrm{P}_{180} \mathrm{~K}_{180}$ & $14.00 \mathrm{c}$ & $2.04 \mathrm{~d}$ & $18.27 \mathrm{~b}$ & $69.15 d$ & $112.39 \mathrm{c}$ & $13.14 \mathrm{~d}$ \\
\hline $\mathrm{LSD}_{5 \%}$ & 0.26 & 0.06 & 0.81 & 6.57 & 20.32 & 0.99 \\
\hline
\end{tabular}

The intensity of soil decomposition microbiological processes can be followed based on the amount of carbon-dioxide production and the nitrate content released. At the same time, MBC and MBN also are excellent indicators of the transformation of soil organic compounds.

Based on the results it can be concluded that the fertilization increased the amount of carbon-dioxide production and net nitrification in both crop rotations. Compared to the same treatments of crop rotations, it can be stated that in tri-culture - with exception of one treatment - the carbon-dioxide production (emission) was higher than in fertilized soils of monoculture. The net nitrification rate was similar in both crop rotations.

Regarding the MBC; every dose of NKP increased this parameter significantly. The MBC values are now $2-3$ fold higher when using a smaller fertilizer dose. It is remarkable that were measured outstanding values in the case of medium-high doses. At the highest fertilizer dose, were found a set of lower values. The quantity of MBC increased in the other long-term fertilization experiment (Luo et al., 2015). The organic fertilizer had significantly higher effect on the MBC, than the mineral fertilizers.

The MBN showed a slight change due to fertilization, especially in monoculture. In both crop rotations significant growth was observed during fertilization, but in tri-culture there were defined higher values than in fertilized treatments of monoculture. 
It is possible that higher organic nitrogen content and $\mathrm{MBN}$, as well as the urease enzyme activity in tri-culture are resulted by the crop rotation. The positive correlation was observed between the urease activity and MBC value by Szili -Kovács et al. (2009) examined in Hungarian soils.

Evaluation of enzymes activity in the soils of experiment

In most cases, the enzymes activity of the soils was stimulated by fertilization depending on the dose used, except for saccharase activity (Table 3). The activity of saccharase enzyme increased in monoculture by the treatments, until tri-culture had lower values and the fertilizer treatments did not significantly affect the enzyme activity.

It can also be stated that in tri-culture the phosphatase and dehydrogenase enzyme activity values were higher in the same treatments than in the soils of the monoculture. The urease enzyme activity showed about 2-3 fold higher activity in tri-culture compared to the same treatments in monoculture.

Bohme et al. (2006) found significantly positive correlation between the organic carbon and microbial biomass carbon (MBC), as well as all of the measured enzyme's activity. Perucci et al. (1997) found significant correlation between the organic carbon content (OC) of soils and all microbiological and biochemical parameters. According their opinion this confirms that the organic carbon has a determining role in the intensity of biological activity.

Table 3. Effects of fertilizer application on enzyme activities in soils of experiment (Debrecen-Látókép Experiment, June 2013)

\begin{tabular}{|c|c|c|c|c|}
\hline \multirow{2}{*}{ Treatments } & $\begin{array}{c}\text { Phosphatase } \\
\text { enzyme }\end{array}$ & $\begin{array}{c}\text { Saccharase } \\
\text { enzyme }\end{array}$ & $\begin{array}{c}\text { Urease } \\
\text { enzyme }\end{array}$ & $\begin{array}{l}\text { Dehydrogenase } \\
\text { enzyme }\end{array}$ \\
\hline & $\begin{array}{c}\left(\mathrm{mg} \mathrm{P}_{2} \mathrm{O}_{5} 100 \mathrm{~g}\right. \\
\left.2 \mathrm{~h}^{-1}\right)\end{array}$ & $\begin{array}{c}\text { (glucose mg } \\
\left.100 \mathrm{~g}^{-1}\right)\end{array}$ & $\begin{array}{c}\left(\mathrm{NH}_{4}^{+} \mathrm{mg}\right. \\
\left.100 \mathrm{~g}^{-1}\right)\end{array}$ & $\begin{array}{c}\left(\text { INTF } \mu g g^{-1}\right. \\
\left.2 h^{-1}\right)\end{array}$ \\
\hline \multicolumn{5}{|c|}{ Monoculture maize } \\
\hline Control & $13.91 \mathrm{a}$ & $6.28 a$ & $11.78 \mathrm{a}$ & $11.78 \mathrm{a}$ \\
\hline $\mathrm{N}_{60} \mathrm{P}_{45} \mathrm{~K}_{45}$ & $14.92 b$ & $6.99 a$ & $13.58 b$ & $13.58 b$ \\
\hline $\mathrm{N}_{120} \mathrm{P}_{90} \mathrm{~K}_{90}$ & $15.84 b$ & $10.12 b$ & $19.23 \mathrm{c}$ & $19.23 \mathrm{c}$ \\
\hline $\mathrm{N}_{180} \mathrm{P}_{135} \mathrm{~K}_{135}$ & $17.47 \mathrm{c}$ & $8.61 c$ & $15.77 d$ & $15.77 \mathrm{~d}$ \\
\hline $\mathrm{N}_{240} \mathrm{P}_{180} \mathrm{~K}_{180}$ & $13.12 \mathrm{a}$ & $8.69 c$ & $9.75 \mathrm{e}$ & $9.75 \mathrm{e}$ \\
\hline $\mathrm{LSD}_{5 \%}$ & 0.96 & 0.65 & 1.48 & 1.48 \\
\hline \multicolumn{5}{|c|}{ Tri-culture maize } \\
\hline Control & $15.60 \mathrm{a}$ & $4.28 \mathrm{ab}$ & $29.32 a$ & $9.98 \mathrm{ab}$ \\
\hline $\mathrm{N}_{60} \mathrm{P}_{45} \mathrm{~K}_{45}$ & $17.15 b$ & $3.96 a$ & $34.93 b$ & $11.28 \mathrm{bc}$ \\
\hline $\mathrm{N}_{120} \mathrm{P}_{90} \mathrm{~K}_{90}$ & $18.77 \mathrm{c}$ & $4.45 \mathrm{ab}$ & $41.39 c$ & $18.33 d$ \\
\hline $\mathrm{N}_{180} \mathrm{P}_{135} \mathrm{~K}_{135}$ & $17.68 \mathrm{bc}$ & $4.66 \mathrm{~b}$ & $29.33 a$ & $12.28 \mathrm{c}$ \\
\hline $\mathrm{N}_{240} \mathrm{P}_{180} \mathrm{~K}_{180}$ & $17.68 \mathrm{bc}$ & $4.62 b$ & $27.58 \mathrm{a}$ & $9.15 \mathrm{a}$ \\
\hline $\mathrm{LSD}_{5 \%}$ & 1.38 & 0.47 & 3.43 & 1.36 \\
\hline
\end{tabular}


Proportions between the different parameters - microbial indexes

The different indexes between the parameters of $\mathrm{C}$ - and $\mathrm{N}$ cycles are shown in the Table 4. Increased fertilizer doses showed a slight increase in the $\mathrm{C} / \mathrm{N}$ ratio. The $\mathrm{C} / \mathrm{N}$ ratio was higher in monoculture treatments than in tri-culture. This result is the same as our previous results (Kátai et al., 2014).Our results were confirmed by the research of Goyal et al. (2006). According to their opinion the decreasing in OC/NO ratio was in the triculture due to the leguminous plant including in crop rotation.

Table 4. Effect of fertilizer application on $C / N, M B C / M B N$ and microbial quotients in soils of experiments (Debrecen-Látókép Experiment, June 2013)

\begin{tabular}{lcccc}
\hline \multicolumn{1}{c}{ Treatments } & $\mathrm{C} / \mathrm{N}$ & $\mathrm{MBC} / \mathrm{MBN}$ & $\begin{array}{c}\mathrm{MBC} / \mathrm{OC} \\
100 \%\end{array}$ & $\begin{array}{c}\mathrm{CO}_{2} / \mathrm{MBC}^{2} \\
\mathrm{qCO}_{2}\end{array}$ \\
\hline \multicolumn{5}{c}{ Monoculture maize } \\
\hline Control & $7.63 \mathrm{a}$ & $7.05 \mathrm{a}$ & $0.36 \mathrm{a}$ & $2.87 \mathrm{c}$ \\
$\mathrm{N}_{60} \mathrm{P}_{45} \mathrm{~K}_{45}$ & $8.27 \mathrm{~cd}$ & $13.95 \mathrm{~b}$ & $0.71 \mathrm{~b}$ & $1.45 \mathrm{~b}$ \\
$\mathrm{~N}_{120} \mathrm{P}_{90} \mathrm{~K}_{90}$ & $8.04 \mathrm{~b}$ & $19.77 \mathrm{c}$ & $1.15 \mathrm{c}$ & $0.95 \mathrm{a}$ \\
$\mathrm{N}_{180} \mathrm{P}_{135} \mathrm{~K}_{135}$ & $8.14 \mathrm{bc}$ & $26.81 \mathrm{~d}$ & $1.67 \mathrm{~d}$ & $0.75 \mathrm{a}$ \\
$\mathrm{N}_{240} \mathrm{P}_{180} \mathrm{~K}_{180}$ & $8.37 \mathrm{~d}$ & $21.62 \mathrm{c}$ & $1.45 \mathrm{e}$ & $0.74 \mathrm{a}$ \\
\hline $\mathrm{LSD}_{5 \%}$ & 0.21 & 3.21 & 0.10 & 0.4 \\
\hline & & Tri-culture maize & \\
\hline $\mathrm{Control}_{60} \mathrm{P}_{45} \mathrm{~K}_{45}$ & $6.4 \mathrm{ab}$ & $4.29 \mathrm{a}$ & $0.33 \mathrm{a}$ & $3.95 \mathrm{~d}$ \\
$\mathrm{~N}_{120} \mathrm{P}_{90} \mathrm{~K}_{90}$ & $6.62 \mathrm{a}$ & $6.78 \mathrm{ab}$ & $0,60 \mathrm{~b}$ & $2.17 \mathrm{c}$ \\
$\mathrm{N}_{180} \mathrm{P}_{135} \mathrm{~K}_{135}$ & $6.99 \mathrm{~b}$ & $11.06 \mathrm{c}$ & $0.97 \mathrm{~d}$ & $1.28 \mathrm{~b}$ \\
$\mathrm{~N}_{240} \mathrm{P}_{180} \mathrm{~K}_{180}$ & $6.98 \mathrm{~b}$ & $26.96 \mathrm{~d}$ & $2.45 \mathrm{e}$ & $0.52 \mathrm{a}$ \\
\hline LSD $_{5 \%}$ & $6.87 \mathrm{ab}$ & $8.56 \mathrm{bc}$ & $0.80 \mathrm{c}$ & $1.62 \mathrm{bc}$ \\
\hline
\end{tabular}

Regarding the $\mathrm{MBC} / \mathrm{MBN}$ ratio, increased in parallel with fertilizer doses, the highest values were counted in the treatment of medium-large and large NPK fertilizer doses in both crop rotations.

The MBC/OC index (0.33-2.45) generally increased by the intensity of treatments of NPK fertilization, which means that in the OC-content of soil the MBC contributed to a higher proportion. Similar results were obtained in previous studies (Kátai, 2006; Kátai et al., 2014). According to other literature data sets (Szili-Kovács et al., 2011) the microbial biomass is the living material of the soil and it constitutes less than $5 \%$ of the organic matter content in soil.

Another soil microbiological index is the specific respiratory activity $\left(\mathrm{CO}_{2} / \mathrm{MBC}\right)$, which expresses the respiration per unit of microbial biomass (Szili-Kovács et al., 2011). With reference to the $\mathrm{qCO}_{2}$, significant decreasing can be observed both in the mono- and tri-culture. In these treatments this ratio $\left(\mathrm{CO}_{2} / \mathrm{MBC}\right)$ decreased generally - Meli et al. (2002) reported the similar results. 
According to Anderson (2003) the higher specific respiratory activity means that more energy is needed to maintain the microbial biomass. This may also indicate the degradation or stress of the microbial communities (Brookes, 1995).

Relationships between microbial parameters in the soil of experiment Correlation analysis among the measured soil parameters were carried out separately in the two crop rotations (Table 5-6). Here will be focused only to the microbial results where the calculations of correlation were similar and close to each other in the two crop rotations. The first number in the parentheses concerns to monoculture the second one to tri-culture.

Both in the monoculture and tri-culture close positive correlations were established between:

- urease and dehydrogenase activities ( $\mathrm{r}=-0.795 ; \mathrm{r}=-0.818$;

- carbon-dioxide production and net nitrification rate (0.697; $\mathrm{r}=0.827)$;

- net nitrification rate and MBN content $(r=0.873 ; r=0.768)$.

Table 5. Relationships between investigated microbial parameters in soil of maize monoculture (Debrecen-Látókép, in June 2013)

(Pearson-correlation; two-tailed; $n=15$ )

\begin{tabular}{|c|c|c|c|c|c|c|c|c|}
\hline $\begin{array}{c}\text { Soil } \\
\text { parameters }\end{array}$ & $\begin{array}{l}\mathscr{U} \\
\tilde{T} \\
\tilde{J} \\
\tilde{J} \\
\tilde{W} \\
\tilde{N}\end{array}$ & 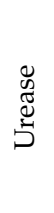 & 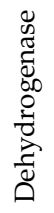 & 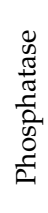 & 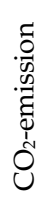 & 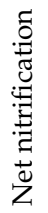 & $\sum_{\Sigma}^{u}$ & $\sum_{\Sigma}^{Z}$ \\
\hline
\end{tabular}

Saccharase

\begin{tabular}{|c|c|c|c|c|c|c|c|}
\hline Urease & $\underset{* *}{0.699}$ & & & & & & \\
\hline Dehydrogenase & $\begin{array}{l}0.593 \\
*\end{array}$ & $\begin{array}{c}0.795 \\
* *\end{array}$ & & & & & \\
\hline Phosphatase & & $\underset{* *}{0.830}$ & $\underset{* *}{0.749}$ & & & & \\
\hline $\mathrm{CO}_{2}$-emission & & $\underset{* *}{0.710}$ & & $\underset{* *}{0.688}$ & & & \\
\hline Net nitrification & & & & & $\underset{* *}{0.697}$ & & \\
\hline MBC & $\underset{* *}{0.710}$ & $\underset{*}{0.600}$ & & & $\underset{* *}{0.867}$ & $\underset{* *}{0.862}$ & \\
\hline MBN & $\underset{*}{0.537}$ & & & & $\begin{array}{c}0.586 \\
*\end{array}$ & $\underset{* *}{0.873}$ & $\underset{* *}{0.816}$ \\
\hline
\end{tabular}

Note: abbreviations - Saccharase enzymes activity=Saccharase; Urease enzyme activity= Urease; Dehydrogenase enzyme activity=Dehydrogenase; Phosphatase enzymes activity= Phosphatase; $\mathrm{MBC}=$ microbial biomass carbon; $\mathrm{MBN}=$ microbial biomass nitrogen. ${ }^{*}$ Correlation is significant at the 0.05 level (2-tailed). ${ }^{* *}$ Correlation is significant at the 0.01 level (2-tailed). 
In monoculture there were close correlations found, while in triculture loose only. These are the following:

- saccharase activity and MBC $\left(r=0.710^{* *} ; \mathrm{r}=0.516^{*}\right)$;

- urease and phosphatase activity $\left(\mathrm{r}=0.830^{* *} ; \mathrm{r}=0.528^{*}\right)$;

- urease activity and carbon-dioxide production $\left(\mathrm{r}=0.710^{* * *} ; \mathrm{r}=0.585^{*}\right)$;

- dehydrogenase and phosphatase enzyme activities $\left(\mathrm{r}=0.749^{* *}\right.$; $\mathrm{r}=0.556^{*}$ );

- $\mathrm{MBC}$ and $\mathrm{MBN}\left(\mathrm{r}=0.816^{* *} ; \mathrm{r}=0.522^{*}\right)$;

- In triculture were determined a close relationship, while in monoculture loose one.

- carbon-dioxide production and MBN $\left(\mathrm{r}=0.814^{* *} ; \mathrm{r}=0.586^{*}\right)$;

- Close relationships were found in monoculture and it were no correlations found in triculture.

- saccharase and urease, activity $\left(\mathrm{r}=0.699^{* *}\right)$;

- phosphatase activity and carbon-dioxide production $\left(\mathrm{r}=0.688^{* *}\right)$.

Table 6. Relationships between investigated microbial parameters in soil of maize triculture (Debrecen-Látókép, in 2013 spring)

(Pearson-correlation; two-tailed; $n=15$ )

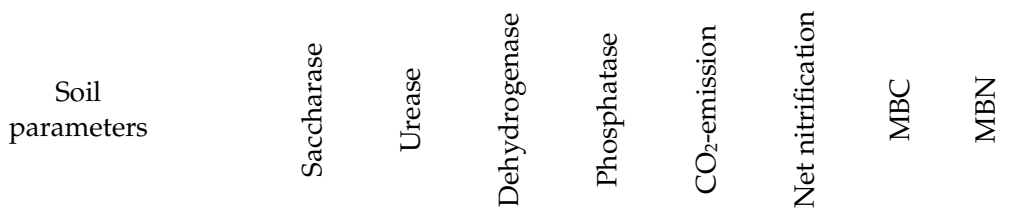

Saccharase

Urease

Dehydrogenase

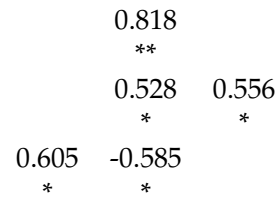

$\mathrm{CO}_{2}$-emission

$* \quad *$

Net nitrification

0.516

MBC

MBN

$\begin{array}{llll}0.612 & 0.814 & 0.768 & 0.522\end{array}$

Note: abbreviations - Saccharase enzymes activity=Saccharase; Urease enzyme activity= Urease; Dehydrogenase enzyme activity=Dehydrogenase; Phosphatase enzymes activity= Phosphatase; $\mathrm{MBC}=$ microbial biomass carbon; $\mathrm{MBN}=$ microbial biomass nitrogen. ${ }^{* *}$ Correlation is significant at the 0.01 level (2-tailed). 
In the case of maize monoculture, 11 different correlations were determined between the examined microbiological parameters. In the two crop rotations from the 11 correlations were common: three close and five lose relationships between various parameters.

\section{Conclusions}

In the $30^{\text {th }}$ years of long-term fertilization experiments (DebrecenLátókép) the different levels of NPK fertilization caused significant positive changes on the most important chemical and biological parameters of soils in both maize monoculture and tri-culture.

In parallel with increasing rate of fertilizer, the soil $\mathrm{pH}$ values decreased significantly while the hydrolytic acidity increased in all treatments and in both crop rotations. The hydrolytic acidity was larger in tri-culture than in monoculture. This result draws attention to compensate the soil acidity in case of medium large and large fertilizer treatments, by liming.

Regarding of the amount of plant available nutrient content and the organic carbon and nitrogen content increased significantly in both crop rotations.

The fertilization stimulated the microbial processes $\left(\mathrm{CO}_{2}\right.$-production, net nitrification rate, $\mathrm{MBC}, \mathrm{MBN}$ ) and some enzyme activities in soils of both crop rotations. In tri-culture the $\mathrm{ON}, \mathrm{CO}_{2}$-production, $\mathrm{MBN}$ as well as the phosphatase and urease enzyme activities proved to be higher than in maize monoculture. At the same time in the monoculture the values of $\mathrm{MBC}$ and saccharase enzyme activity were larger compared to the triculture.

\section{Acknowledgement}

The publication is supported by the EFOP-3.6.3-VEKOP-16-2017-00008 project. The project is co-financed by the European Union and the European Social Fund.

We are grateful to Professor Péter Pepó, Head of Institute of Plant Sciences of Debrecen University for giving for us the opportunity to take soil samples for analysis from the long-term fertilization experiments in Debrecen-Látókép.

\section{References}

Anderson, T. H. (2003): Microbial eco-physiological indicators to asses soil quality. Agr. Ecosyst. Environ. 98: 285-293. 
Balezentiene, L. (2014): Indicating Soil Quality Using Urease and Saccharase activity in Abandoned Grassland and Differently Managed Crop Fields. [In: Sokolovic, D. et al. (eds.) Quantitative Traits Breeding for Multifunctional Grasslands and Turf.] Springer Verlag. Dordrecht.

Blaskó L.-Zsigrai Gy. (2017): A mútrágyázás és a mészállapot összefüggései réti csernozjom talajon (Karcag). [In: Blaskó L.-Zsigrai Gy. (szerk.) Mútrágyázás, talajsavanyodás és a meszezés összefüggései az OMTK kísérlethálózat talajain. 2. kiadás.] Karcag-Keszthely. 107-136.

Buzás, I. (ed.) (1988): Methods of soil and agricultural chemistry analyses 2. Physical-chemical and chemical methods of soil analyses. Mezőgazdasági Kiadó. Budapest. 90-93.

Bohme, I.-Bohme, F. (2006): Soil microbiological and biochemical properties affected by plant growth and different long term fertilisation. European Journal of Soil Biology. 42. 1: 1-12.

Brookes, P. C. (1995): The use of microbial parameters in monitoring soil pollution by heavy metals. Bio. Fert. Soils. 19: 269-279.

Egnér, H.-Riehm, H.-Domingo, W. R. (1960): Untersuchungen über die chemische Bodenanalyse als Grundlage für die Beurteilung des Nährstoffzustandes der Böden. II. K. LantbrHögsk. Ann 26. 199-215.

Felföldy, L. (1987): Biological Water Qualification. Fourth Edition. Vízügyi Hidrológia. Vízgazdálkodási Intézet. Budapest. 16: 172-174.

Filep, Gy. (1988): Soil Analysis. Lecture Notes. University of Agricultural Sciences. Debrecen. 105-107.

Frankerberger, W. T.-Johanson, J. B. (1983): Method of measuring invertase activity in soils. Plant and Soil. 74: 301-311.

Geisseler, D.-Scow, K. M. (2014): Long-term effects of mineral fertilizers on soil microorganisms. A review. Soil Biology and Biochemistry. 75: 54-63.

Goyal, S.-Sakamoto, K.-Inubushi, K.-Kamewada, K. (2006): Long-term effects of inorganic fertilization and organic amendments on the organic matter and soil microbial properties Andisols. Archives of Agronomy and Soil Science. 52: 617625.

Janusauskaite, D.-Arlauskiene, A.-Maikteniene, S. (2013): Soil mineral nitrogen and microbial parameters as influenced by catch crops and straw management. Zemdirbyste Agriculture. 100. 1: 9-18.

Kátai, J. (2006): Changes in soil microbiological properties in long-term fertilization experiments. Agrokémia és Talajtan. 48. 3-4: 348-358.

Kátai, J.-Zsuposné Oláh, Á.-Sándor, Zs.-Tállai, M. (2014): Comparison of soil parameters of the carbon and nitrogen cycles in a long-term fertilization field experiment. Agrokémia és Talajtan. 63. 1: 129-138.

Kátai, J.-Zsuposné Oláh, Á. (2015): Changes in soil chemical features and microbiological characteristics connecting to carbon and nitrogen cycles in Hungarian long term experiment. Aspects of Applied Biology 128. Validating long term sites and experiments for agriculture and ecology. 225-230.

Kátai J.-Pepó P.-Sárvári M. (2017): Talajtani és növénytermesztési kutatások tartamkísérletekben. Talajok gyógyítója - Blaskó Lajos 70 éves. 173-189.

Mersi, V. W. (1996): Dehydrogenase Activity with the substrate INT. [In: Schinner, F. et al. (eds.) Methods in Soil Biology.] Springer-Verlag. Berlin-Heidelberg. 243-245. 
Öhlinger, R. (1996): Soil respiration by titration. Phosphomonoesterase Activity with the substrate phenylphosphate. [In: Schinner, F. et al. (eds.) Methods in Soil Biology.] Springer-Verlag. Berlin-Heidelberg. 93-98., 210-213.

Pepó P. (2001): A genotípus és a vetésváltás szerepe a kukorica tápanyag ellátásában csernozjom talajon. Növénytermelés. 50. 2-3: 189-202.

Perucci, P.-Bonciarelli, U.-Santilocchi, R.-Bianchi, A. A. (1997): Effect of rotation, nitrogen fertilization and management crop residues on some chemical, microbiological and biochemical properties of soils. Biology and Fertility of Soil. 24. 3: 311-316.

Pulleman, M.-Creamer, R.-Hamer, U. (2012): Soil biodiversity, biological indicators and soil ecosystem service an overview of European approaches. Current opinion in environmental sustainability. 4. 5: 529-538.

Sárvári M. (1995): Monokultúrás termesztés hatása a kukorica termésére réti talajon, mútrágyázási tartamkísérletben. Növénytermelés. 44. 4: 359-374.

Sárvári M.-Szabó P. (1998): A termesztési tényezők hatása a kukorica termésére. Növénytermelés. 47. 2: 213-221.

Simon, T.-Tako, A. (2014): Influence of long-term application of organic and inorganic fertilizers on soil properties. Plant Soil and Enviroment. 60: 314-319.

Székely, Á.-Schlick, B.-Szabó T.-né (1960): On the photometric and colorimetric determination of organic carbon. Agrokémia és Talajtan. 9: 111-120.

Szili-Kovács, T.-Zsuposné Oláh, Á-Kátai, J.-Villányi, I.-Takács, T. (2009): Correlation between biological and chemical properties in soils from long-term experiments. Agrokémia és Talajtan. 58: 309-325.

Szili-Kovács T.-Kátai J.-Takács T. (2011): Mikrobiológiai indikátorok alkalmazása a talajminőség értékelésében 1. Módszerek. Agrokémia és Talajtan. 60: 273-286.

Vance, E. D.-Brookes, P. C.-Jenkinson, D. S. (1987): An extraction method for measuring soil microbial biomass-C. Soil Biol. Biochem. 19: 703-707.

Zhao, B.-Chen, J.-Zhang, J.-Xin, X.-Hao, X. (2013): How different long-term fertlization strategies influence crop yield and soil properties in a maize field in the North China Plain. Journal of Plant Nutrition and Soil Science. 176. 1: 99109. 